\title{
Foreign and domestic investment: Regional Development or Crowding out?
}

\author{
Nigel Driffield \\ Business School, \\ Birmingham University, \\ Edgbaston, \\ Birmingham, B15 2TT \\ and

\section{Dylan Hughes*} \\ Barclays Global Investors \\ Murray House \\ 1 Royal Mint Court \\ London EC3N 4HH
}

\begin{abstract}
This paper tests at the regional and industry level, the extent to which domestic investment is stimulated, or crowded out by inward foreign direct investment. The paper develops a model of domestic investment, based on standard models drawn from macroeconomics and industrial economics. The paper then goes on to show that at a general level, the 'development' or agglomeration hypothesis is confirmed that indeed domestic investment is stimulated by inward investment. However, there is also evidence that in certain regions, inward investment has crowded out domestic investment. The implications of this, from the perspective of regional policy are briefly discussed.

Keywords: Inward investment, domestic investment, crowding out. JEL classification. D24, F23

\footnotetext{
* Thanks are due to David Bailey, John Dewhurst, Holger Görg, Jim Love, Max Munday and Colin Wren, for comments on an earlier draft of this paper. Dylan Hughes acknowledges with thanks the financial assistance of the Welsh Development Agency. No statement herein is to be construed as a recommendation or solicitation to buy or sell securities or to provide investment or legal advice. Any views or opinions expressed in this article are those of the author and do not necessarily reflect the views or opinions of Barclays Global Investors Limited or of the Barclays group.
} 


\section{INTRODUCTION}

For more than 20 years the UK has been encouraging investment from abroad, by spending substantial sums on marketing the UK and its regions around the world, and providing location incentives for investors. Such spending has been justified on the basis of both job creation, and the gains to domestic industry via greater competition and thus increased domestic performance. Partly as a result of this spending, the UK has received more inward investment than any other European Union member state since 1980. The UK attracted 41\% of all Japanese investment between 1984 and 1991, some 9\% of total Japanese FDI and 21\% of all US FDI since 1987 (Driffield, 1999a).

Particular regional development corporations, such as the Welsh Development Agency, Scottish Enterprise, and One NorthEast ${ }^{i}$, have been concerned with attracting inward investment, and the 1980s witnessed an upsurge in foreign investment with an increasing tendency to locate in peripheral regions. Wales, Scotland and the North of England all attracted shares of FDI out of proportion to their size.

\section{Figures 1 and 2 here}

Figures 1 and 2 illustrate the changing patterns of ownership within the UK over the period, and the regions that have increased their foreign shares significantly. It is also noticeable that some industries, notably office machinery and transport have, as is well known, experienced large scale inward investment, starting from a high base in the early 1980s. This pattern is well understood now, but detailed discussion of these industry and regional trends can be found in Driffield (2001a)

This paper examines one potential impact of this large scale FDI, the effect on levels of domestic investment, both at the regional and sectoral level. Previous work in this area is 
rather contradictory. De Mello (1999) for example suggests that one effect is 'capital deepening', that domestic firms respond to FDI by increasing and updating their capital stock. Aitken and Harrison (1999) and Buffie (1993) however suggest that domestic firms experience increased competition as the result of FDI, thus reducing their output, and at least in the short term, investment. Hejazi and Pauly (2001) report a similar result for Canada, arguing that inward investment has the effect of replacing, rather than supplementing domestic capital formation.

The paper is set out as follows: Sections 2 and 3 examine at the potential effects of foreign direct investment, both beneficial and adverse impacts on the host region. Section 4 derives a suitable model to test the hypotheses that the paper outlines, and the data and methods used in the econometric analysis are described in section 5. The results and conclusions of this paper are in Sections 6 and 7 respectively.

\section{THE BENEFITS OF FOREIGN DIRECT INVESTMENT}

New foreign manufacturing investment can have beneficial economic consequences, particularly within disadvantaged or peripheral areas. In the UK, foreign inward investment has assisted regional development policy, providing jobs and incomes in areas hit hardest by structural decline in traditional industry. In addition to job creation and resource transfer, foreign inward investments also provides new trading opportunities, and technology and skills transfer to supplier and customer sectors. Moreover, the presence of multinational enterprises can have other beneficial effects on indigenous industry and allied sectors. Multinational enterprise may provide a basis for technology spillovers and the development of innovatory capacity in domestically owned sectors (Blomström and Sjoholm, 1999). These externalities may be in the form of knowledge 
spillovers or demonstration effects, and will be greatest where significant linkages develop between the foreign and domestic sectors. This is an argument that dates back to Hirschman (1958), that economic development is accelerated by investment in projects and industries with strong backward or forward linkages. When considering the type of industry suitable to locate in underdeveloped regions, the growth and development of linkages with the indigenous sector has been emphasised as an important aspect of the overall development.

The significance of these spillovers was demonstrated by Barrell and Pain (1997), who estimated that around $30 \%$ of the productivity growth in UK manufacturing between 1985 and 1995 could be associated to the impact of inward investment. The 'ripple through' effects of changes in production and working practices triggered by the presence of new inward investors have been particularly important.

Linked to the spillover benefits of FDI, are the potential agglomeration economies associated with FDI. Models of regional development, that are based on agglomeration and capital mobility, essentially model economic development as a path dependent process, see for example Markusen and Venables (1999). The importance of agglomeration economies, both in the context of regional / industrial development, and in the determinants of efficiency or productivity have been understood for some time. Equally, agglomeration economies have long been assumed to be a contributing factor in explanations of industrial location. Ellison and Glaeser (1999) for example, show that agglomeration economies contribute to intra industry technology spillovers, as do Paul and Seigel (1999). 
Equally, agglomeration economies have been found to be important in the determinants of the location of international production, Head et al (1999), and in the location of innovation activities, Cantwell (1991). The theoretical basis for the importance of agglomeration, and particularly agglomeration based on the ability to attract FDI, is derived from theoretical models of industrial development, see for example Markusen and Venables (1999). Markusen and Venables show that inward investment into a region will not only stimulate domestic activity, but that this domestic development may eventually replace the original FDI. This result is dependent on the phenomenon generally described as the linkage effect, and is well documented in the regional science and technology spillovers literature, see for example Young et al (1989) or Driffield (2001b). Here, linkages are developed between the foreign and domestic sectors, which with complementarities and scale economies stimulate development in the domestic sector and contribute to regional agglomeration economies. Markusen and Venables (1999) demonstrate that from a theoretical perspective it is possible for the linkage effect to dominate, and therefore that FDI can contribute to regional development. Indeed, Markusen and Venables (1999) show that under certain circumstances agglomeration economies in the domestic sector can develop to the extent that the foreign investment is no longer profitable, and exit is induced. This is clearly attractive from a policy perspective therefore, and explains why so many studies have concentrated on evaluating the scale and scope of linkages between the foreign and domestic sectors, (RodriguezClare, 1996), and the contribution of inward investment to agglomeration economies (Driffield and Munday, 2000). 
In the UK context, evidence is emerging of potential spillovers from inward investment, Driffield (2001b) and Wakelin and Girma (2000). However, these results also demonstrate that the impact of FDI is largely dependent on the extent to which MNEs introduce new technology to the UK, and the ability of the domestic firms to assimilate this technology. Görg and Strobl (1999) however show, that in Ireland, inward investment has stimulated domestic entry, particularly in high technology industries.

\section{POSSIBLE ADVERSE EFFECTS OF INWARD INVESTMENT.}

Markusen and Venables (1999) argue that FDI only has costs or benefits to local economies as a result of microeconomic imperfections and imperfect competition. Aitken and Harrison (1999) in a different context, find a similar result. Aitken and Harrison (1999) argue that the likely impact of inward investment on domestic productivity should be separated into two effects. In addition to the standard productivity gains argument, Aitken and Harrison (1999) explain an effect that occurs through increased competition. The foreign firm captures some of the domestic firms' market shares, forcing them to operate at a smaller scale, reducing output and (possibly) increasing unit cost. This is expected to be significant in imperfectly competitive markets, and is similar to the result reported by Driffield and Munday (1998).

Buffie (1993) expresses particular concerns that inward investment simply has the effect of reducing domestic output. Holden and Swales (1995) discuss the importance of displacement, particularly in the context of regional policy. They show that with the advent of more discretionary investment or employment subsidies, then the impact on the incumbent firms may be greater than otherwise anticipated, and displacement of such output or employment increased. 
The issue of increased displacement from FDI is also linked to the nature of the ownership advantages that MNEs are assumed to possess. There is evidence that inward investment acts to increase industry wages (Driffield, 1999a), and that domestic firms respond by reducing employment. FDI therefore may cause a reduction in employment in the UK sector in which it occurs. An increase in the equilibrium wage rate has a serious effect on certain industries in the UK and the regions where they are located, and this phenomenon is intensified for the following reasons.

- Faced with increased competition in product markets, domestic firms reduce their output.

- Domestic firms also face factor market effects (the increased demand for factors leads to an increase in price) reducing employment levels.

These adverse effects suggested by Driffield (1999a) and Hamill (1993) in terms of labour may also apply to levels of capital held by firms. If foreign firms have a productivity advantage over their domestic counterparts, it is likely that they will be willing to pay higher prices for capital goods. In industries with significant foreign penetration, a possible result is that the cost of capital goods will increase in the domestic sector, and investment by the domestic UK firms will decline. The importance of this is that it is possible for investment to decline in the domestic sector, even if the sales of the foreign firms merely replace its imports. Any inward investor possessing a productivity advantage, and therefore is willing to pay a higher price for capital, can expect to generate a reduction in domestic investment. 
It is with these adverse effects, as well as the benefits of inward investment in mind that the effect of FDI on domestic investment will be established. The model used to test this hypothesis is outlined in the following section.

\section{A MODEL OF DOMESTIC CAPITAL FORMATION}

Standard models of the optimal level of capital services are based on the work of Nickell (1979), Pfann (1996), or Thomsen (2000).

The theoretical approach is based upon a simple structural model of the capital market highlighting the role of alternative domestic and foreign wages as comparison incomes on the supply side. For exposition, we assume a Cobb-Douglas production function for the domestic sector, of the form: $Q=A K^{\alpha_{k}} L s^{a_{s}} L u^{a_{u}}$ where $Q$ is output, $K$ is capital and labour $L$ is split into skilled Ls and unskilled $\mathrm{L} u$.

It is trivial then to show that the optimal level of capital for the firm can be determined from: $K^{1-\beta_{k}} A \alpha L s^{\beta_{s}} L u^{\beta_{u}}=r$

Koechlin (1992) develops a model in order to establish whether investment conditions abroad motivate firms to reduce their investment decisions at home. Koechlin (1992) for example uses profits $\left(\Pi_{t}\right)$ and income $\left(\mathrm{Q}_{\mathrm{t}}\right)$ as the main determinants of investment, as do Catinat et al (1988). The importance of variables such as profitability, or expected profitability, in the supply of funds for investment, is discussed at length in Nickell (1979) for example. The required rate of return for potential suppliers of finance is therefore given by:

$r=K^{\eta} Q^{\rho} K F^{\psi}$ 
Foreign investment in the UK (KF) is also included here, following the arguments outlined above. The sign of $\psi$ is essentially an empirical question, determined by which the two main effects of inward investment (crowding out or agglomeration) dominates. So we have a structural model for capital demand and supply, given by the following two equations derived from logarithmic transformations of equation 1 and 2:

The reduced form for the capital stock is given by

$$
\ln K=\theta+\gamma_{1} \ln \Pi+\gamma_{2} \ln Q+\ln \gamma_{3} \ln L s+\gamma_{4} \ln L u+\gamma_{5} K F
$$

Where the labour inputs control for factor substitution or factor complementarity effects, while output (Q) allows for any exogenous change in local output, either due to change in demand in the product market, or the relocation decision of the firm for example.

However, the development of a firm's capital stock is generally assumed to follow a partial adjustment process, as the firm moves to wards optimal capital levels. Partial adjustment arises because firms are presumed to operate in imperfect capital markets that prevents them from fully adjusting when financial structure deviates from its target and also prevent optimal funding of new investment spending. The primary hypothesis in this case is that the speed of adjustment coefficients is positive but less than unity, see for example Hall (1992), Nickell (1979) ${ }^{\mathrm{ii}}$. Thus, the expression for the actual capital stock of the firm becomes:

$\ln K_{\mathrm{t}}=\beta_{0}+\gamma \ln K_{t-1}+\beta_{1} \ln Q_{t} \beta_{2} \ln L s_{t}+\beta_{3} \ln L u_{t}+\beta_{4} \ln K F_{t}+\beta_{5} \ln \Pi_{t}+e_{t} . .(4)$

where the error term is represented by $e_{t}$.

Equation (4) however does not allow the impact of FDI on domestic investment to vary either across industries or across regions. This is a key question for policy makers, as different regions attract different levels of inward investment, and for different reasons. 
The "peripheral" areas of the UK, such as Wales, Scotland, Ulster and the North of England, have sought to attract FDI through subsidy, in order to alleviate the symptoms of structural unemployment. Other regions, such as the South East of England, have also attracted large quantities of inward investment, without offering large subsidies. It is therefore necessary to test for the differing regional effects of inward investment in terms of equation (2). One possibility for doing this, is to split the sample by assisted area status, that is, test whether the coefficients are consistent between regions that are able to offer subsidies to attract inward investment, and those that are not. Equally, different industries may experience different impacts of FDI, as outlined by Markusen and Venables (1999) discussed above. Any results generated by estimating (4) may be influenced by the fact that different regions will have different mixed of industries, which may exaggerate any regional differences in the impacts of FDI. In order to do this, one requires that the data be stratified, not only be region, but also by industry, as well as time. Testing for differential effects across regions or industries is therefore achieved through the use of slope dummies in the foreign investment term. Thus, the equation that is estimated becomes:

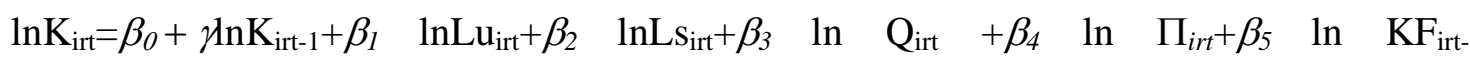
$\left(\sum_{i=1}^{19} \mu_{i} D_{i}+\sum_{r=1}^{10} \phi_{r} D_{r}\right) K F_{i r t}+\mathrm{a}_{\mathrm{ir}}+\mathrm{v}_{\mathrm{t}}+e_{i r t}$

for $(r=1, \ldots 10),(i=1, \ldots 19)$

where $\mathrm{a}_{\mathrm{ir}}$ are the individual effects, and $\mathrm{v}_{\mathrm{t}}$ the time effects.

where $D_{r}$ represents a regional dummy for the 11 regions, and $D_{i}$ represents an industry dummy for the 20 industries. The full classification of the numbered regions and industries is provided in Appendix 1. Equation (5) can therefore be estimated, in order to 
determine the impact on domestic investment of inward investment across industries or regions. ${ }^{\mathrm{iii}}$

\section{ECONOMETRIC ANALYSIS}

The Estimation of (5) with panel data, where a lagged dependent variable is included, as is now well understood, requires that the data be transformed to first differences. With the data stratified by both industry, and region, as well as time. Thus, equation (3) becomes:

$\mathrm{k}_{\mathrm{irt}}=\gamma k_{\mathrm{irt}-1}+\beta_{1} l u_{\mathrm{irt}}+\beta_{2} l s_{\mathrm{irt}}+\beta_{3} q_{\mathrm{irt}}+\beta_{4} \pi_{\mathrm{irt}}+\beta_{5} k f_{\mathrm{irt}}+\left(\sum_{i=1}^{19} \mu_{i} D_{i}+\sum_{r=1}^{10} \phi_{r} D_{r}\right) k f_{\mathrm{irt}}+\varepsilon_{\mathrm{irt}}$

Lower case denotes differences in logs.

A generalised method of moments approach is then employed, following Arrelano and Bond (1989, 1991). The differencing removes the problem that the lagged dependent variable is correlated with the fixed effects, see Keane and Runkle (1992).

The estimation of (6) therefore requires that the lagged dependent variable is treated as endogenous, as it is related to the error term, and is therefore instrumented. Suggested instruments, following Baltagi (1995) are further lags of $k_{i r t}$ and $K_{i r t}$. In addition, $q_{i r t}$, $\pi_{\text {irt, }} l u_{i r t}$ and $l s_{\text {irt }}$ are assumed to be endogenous, and are therefore also instrumented with lagged values. Foreign investment, KF, is also instrumented with lags for similar reasons. The Sargan test statistic for the appropriateness of these instruments is reported in table 1 with the results.

In addition, with a model and data of these type, there is the potential problem of regional dependence, or regional autocorrelation. These phenomena are well understood within the regional science literature, see for example Anselin and Florax (1995) and Anselin 
and Kelejian (1997) and the references contained therein. The usual tests suggest that these problems do not present themselves here. A final consideration with these type of data, is that the model overall generates coefficients that are not consistent across core and periphery regions of the economy. With these data, it is easy to identify areas that have assisted area status ${ }^{\mathrm{iv}}$, and those that do not. Equation 6 was then also run on the 2 sub samples separately, the results being reported in tables $2 \mathrm{a}$ and $2 \mathrm{~b}$.

\section{THE DATA}

The data were provided by Office of National Statistics (ONS), stratified by region industry and time for the whole of the UK, and also for the foreign owned sector separately. These are the data on which the Annual Business Inquiry (ABI), formerly the Census of Production (CP)is based. Lengthy descriptions of the data collection process are available in each annual volume of the ABI/ CP. While only plants employing over 100 people are surveyed every year, and those employing 20-99 people every four years, large samples of small firms are also included, such that some 400000 plants are covered to construct the data. Further discussion of the methodology is provided in Jones (2002). A key feature of these data therefore is that they allow for the calculation of the domestically owned sector separately, so that one can study directly the impact of new inward investment on the domestic sector of the economy. These data are at the 2 digit level manufacturing sectors, across the standard planning regions of the UK. ${ }^{\mathrm{v}}$ This unit of analysis is the level of regional aggregation is the level at which most policies are considered. The areas covered by the large regional development agencies are analogous to these standard-planning regions, with such agencies concerned to determine the effectiveness of policy initiatives at this level. While these data provide exceptionally 
good coverage, they are nevertheless sectoral / regional data rather than firm specific data. This may present problems in standard models of externalities, in the presence of changes in input mixes at the firm level in the presence of technological externalities. However, Görg and Strobl (2001) show that in such cases, aggregation bias does not seem to present a significant problem. In a model such as the one presented here, where one is seeking to identify industry / regional level responses, and the specification of externalities is not the central issue, aggregation bias is not expected to present a significant problem. These data are available from 1984 to 1997, however, there was a change in industry and employment classifications in 1992, so a consistent time series is not available, as it is impossible to completely tie in the two industry classifications. A further difference is that there is no consistent skilled / unskilled worker distinction for the second period, so merely "total employment" is included in the model employed for the latter sample. Nevertheless, a panel with a wide cross section (220 observations in the first period, 253 in the second) with two relatively long time series (9 years and 5 years respectively) may be generated, thus allowing for modern panel data techniques to be employed. Econometric work has therefore to be done on two separate sub samples. The definitions of the variables used are provided in appendix one, while the definitions of the industries for both time periods given in appendix 2 .

\section{RESULTS}

Table 1 here

The results from the estimation of (6) on the full sample are presented in table 1 . The appropriate lag length to be applied to the inward investment variables was also investigated, confirming a lag of one year. The test statistics for this are provided at the 
bottom of table 1 , along with the tests for serial correlation, spatial dependence, spatial correlation and other inter-regional effects.

These results show clearly that the impact on domestic investment of inward investment is positive. The reference region is the South East of England, while the reference industry is the miscellaneous manufacturing category (SIC49 and NACE 36). The results confirm the general hypotheses taken from the literature, that internal sources of funds are important determinants of domestic investment, and that there is significant persistence in firms' planned investment. These results are consistent across both time periods. It is also clear that for the earlier sample at least, skilled labour has a higher degree of complementarity with capital, than unskilled labour.

Overall therefore, it can be seen that the significant inflow of FDI into the UK in recent years has had the effect of boosting manufacturing investment in the domestic sector. This suggests therefore that there are indeed 'developmental' linkages between foreign and domestic companies, and that this effect is particularly strong in sectors such as motor vehicles and transport equipment for example. However, what is equally notable is that there are several industries where the dummy variables are negative, such that the impact of FDI is less favourable than the base region (the miscellaneous group). There are several alternative explanations for this, which should not necessarily be seen as mutually exclusive. The first is that inward investment 'crowds out' domestic firms. The domestic sector, observing new competition, from perhaps a larger, or technologically superior firm, possibly also in receipt of a subsidy, determines that the domestic market share will be reduced, and therefore reduces investment. A more extreme possibility is that domestic firms exit the industry, being unable to compete with the foreign investor. 
Perhaps of more concern however, are the negative regional dummies. Wales, Scotland and the other peripheral areas have all targeted inward investment as a major contributor to regional development. There is evidence that in these cases FDI acts to reduce domestic investment, even allowing for industry effects. The regions that appear to have suffered the greatest crowding out effects, are those that have spent large amounts of public money on attracting inward investment as part of their regional development strategies.

This distinction is perhaps more stark when one considers table $2 \mathrm{a}$ and $2 \mathrm{~b}$. While in general the model performs well across the two sub samples for both time periods, although several differences emerge.

Table 2a and 2b here

Output and profitability are clearly more important in determining domestic investment in assisted areas than in non-assisted areas. This is not surprising, as firms in these areas face tighter capital constraints, and have to rely on internal sources of finance rather than external capital markets. More important however is the difference in the impacts of inward investment across the two sub samples. The coefficient on FDI is negative for this group, suggesting that there is evidence of crowding out in the assisted areas, those that have sought successfully to attract inward FDI over the period. In the non-assisted areas, there is significant evidence of the developmental effects of FDI, although these appear to have been smaller for the latter sample.

One possible explanation for the different effects across assisted areas and non-assisted areas is that domestic firms in assisted areas are not able to compete with MNEs, and therefore exit industries that experience large scale FDI. A further possibility is that the 
purchasing policies of MNEs contribute to this. Phelps $(1993)$ and Turok $(1993,1996)$ for example show that local sourcing by MNEs in such regions is low, and that many 'locally produced' inputs are produced by secondary investors with vertical relations with the MNE. The obvious exception here is Northern Ireland, which shows large positive effects of FDI. It is clear that the domestic sector in Northern Ireland has been dependent on inward investment, often in receipt of large subsidy. It may be that foreign investment in Northern Ireland is more "embedded" than in other parts of the UK, although an alternative scenario is that domestic investment during this period was only stimulated by the exogenous shock to investment that was caused by FDI. ${ }^{\mathrm{vi}}$

It is possible, from the results presented in table 1 , to calculate the individual industry/region effects of inward investment on domestic capital formation by summing the various coefficients on the dummy variables and the coefficient on the reference group, and to determine significance using $\mathrm{z}$ statistics ${ }^{\mathrm{vii}}$. These are presented in table 3 . Many of the industry specific effects for Wales and Scotland in particular are negative, although several are insignificant. The higher-earning areas of the UK however demonstrate significant agglomeration effects of inward investment. The West Midlands have clearly benefited significantly from inward investment, as to a lesser extent have Yorkshire and East Anglia. Equally, regions that have been successful in attracting inward FDI in sectors such as motor vehicles and chemicals, industries that are known to have well developed supply chains and high levels of outsourcing have benefited significantly. Equally, inward investment in man made fibres appears to stimulate domestic investment. 


\section{CONCLUSIONS}

This paper has demonstrated that in general, inward investment stimulates domestic investment, confirming one of the hypotheses of Markusen and Venables (1999), and others, that complementarity and agglomeration economies are generated as a result of FDI. This clearly therefore provides support for regional development agencies, who have sought to attract inward investment with large-scale subsidies. However, there is also evidence of competitive or displacement effects, particularly in regions such as Scotland, Wales and the North of England. One possible explanation for this is taken from the spillovers literature, for a recent example see Blomström et al (1999). This suggests that an important determinant of the extent of spillovers from FDI, is the technology gap between the foreign and domestic sectors. In cases where host regions or industries exhibit only low levels of physical and human capital intensity, then such firms may not be able to assimilate any technology externalities that occur as a result of inward investment. Linked to this is the type of FDI that is attracted to such locations. Where firms are attracted to a region because of low wages, or simply because of a capital or employment subsidy, then the activities undertaken by the foreign firm may be low skill, low value added activities. In such cases, technology spillovers will again be limited, and the displacement effect will dominate.

While these results do suggest that the overall benefits from FDI may not be as large as suggested elsewhere, this is not to say that the results presented here provide evidence that these regions are worse off as a result of FDI. It is clear that inward foreign direct investment generates employment that may not have occurred in the absence of inward investment. These results do however suggest that regional development agencies and 
other policy making bodies should engage in more sophisticated targeting in their use of subsidies as part of their regional economic strategies, focussing on certain industries rather than offering more generic subsidies. It is possible that agglomeration benefits take longer to develop than do the displacement effects. However, within the methodological framework employed here, there is no evidence of any further lags on the foreign investment variables being significant. Further research is however clearly required in order to further examine the distinction between the short and long run effects, and the potential inter-industry effects generated by backwards and forward linkages. 


\section{Appendix 1. Definitions of the variables}

All the data are annual, and the data used are the differences between 1984 and 1992. All monetary variables are expressed in real terms (1992 prices).

Q is value added for the domestic sector, as defined in the Report on the Census of Production.

$\mathrm{K}$ is the capital stock of the domestic industry, the change in this is given by net capital investment, in the UK owned sector. This is expressed in $£$ millions. Data on the capital stock are not available at this level of aggregation, so the sum of net investment over the previous ten years is used as a proxy. A standard depreciation rate of $10 \%$ is used.

PROFIT : Profits are calculated as value added - wages and salaries -capital costs ${ }^{\text {viii }}$ To prevent collinearity with output, these are then transformed to $\Pi / K$, using the capital stock data.

$\mathrm{Lu}$ is employment of unskilled worker sin domestic owned industry. (earlier sample only)

Ls is employment of skilled workers in domestic owned industry. (earlier sample only)

$\mathrm{L}$ is total employment in domestic owned industry (later samples only)

KF is the measure of foreign capital, calculated in the same manner as domestic capital.

The regions are specified as the standard planning regions used by ONS. 


\section{Appendix 2:}

Definitions of SIC (1980) codes :

Metal Manufacturing $\quad 22$

Extraction of Minerals $\quad 23$

Manufacture of Non-Metallic mineral products $\quad 24$

Chemical Industry $\quad 25$

Production of man-made fibres $\quad 26$

Manufacture of metal goods $\quad 31$

Mechanical engineering $\quad 32$

Manufacture of office machinery \& data processing equipment 33

Electrical \& electronics engineering $\quad 34$

Manufacture of motor vehicles \& parts thereof 35

Manufacture of other transport equipment 36

$\begin{array}{ll}\text { Instrument engineering } & 37\end{array}$

Textile industry $\quad 43$

Manufacture of leather \& leather goods $\quad 44$

Footwear \& clothing industries $\quad 45$

Timber \& wooden furniture industries $\quad 46$

Manufacture of paper \& paper products; printing \& publishing $\quad 47$

$\begin{array}{ll}\text { Processing of rubber } \& \text { plastics } & 48\end{array}$

$\begin{array}{ll}\text { Other manufacturing industries } & 49\end{array}$

Definitions of NACE (1992) codes

Food products, beverages $\quad 15$

$\begin{array}{lr}\text { Tobacco } & 16\end{array}$

$\begin{array}{ll}\text { Textiles } & 17\end{array}$

$\begin{array}{ll}\text { Wearing apparels, dressing of fur } & 18\end{array}$

$\begin{array}{ll}\text { Leather, Leather products } & 19\end{array}$

$\begin{array}{ll}\text { Wood and wood products } & 20\end{array}$

$\begin{array}{ll}\text { Pulp, paper } & 21\end{array}$

$\begin{array}{ll}\text { Publishing, printing } & 22\end{array}$

Manufacture of coke and refined petroleum products 23

Chemicals, man made fibres $\quad 24$

$\begin{array}{ll}\text { Rubber, plastic } & 25\end{array}$

Other non metallic products $\quad 26$

$\begin{array}{ll}\text { Basic metals } & 27\end{array}$

Fabricated metal products (except machinery) 28

$\begin{array}{ll}\text { Machinery, equipment } & 29\end{array}$

Office machinery and computers $\quad 30$

Electrical machinery $\quad 31$

Radio, TV and communication apparatus $\quad 32$

Medical, optical, watches $\quad 33$

Transport equipment: Motor vehicles, Trailers 34

Transport equipment: other transport equipment 35

$\begin{array}{ll}\text { Manufacturing n.e.c., including furniture } & 36\end{array}$

$\begin{array}{ll}\text { Recycling } & 37\end{array}$ 


\section{REFERENCES}

AITKEN B.J. and HARRISON A.E. (1999). Do domestic firms benefit from direct foreign investment? Evidence from Venezuela ? American Economic Review 89 605618.

ANSELIN L. and FLORAX R.J.G.M (1995) Small sample properties of tests for spatial dependence: Some further results. In ANSELIN L. and FLORAX R.J.G.M (eds) New directions in spatial econometrics. Springer, Berlin

ANSELIN L. and KELEJIAN H.H. (1997) Testing for spatial error autocorrelation in the presence of endogenous regressors. International Regional Science Review, 20 153-182.

ARELLANO M. and BOND S. (1988) Dynamic panel data estimation using DPD, a guide for users. Institute for Fiscal Studies working paper.

ARELLANO M. and BOND S. (1991) Some tests of specification for panel data: Monte Carlo evidence and an application to employment equations. Review of Economic Studies, 58 277-97.

BALTAGI B. (1995), Econometric Analysis of Panel Data. Wiley, Chichester.

BARRELL R. and PAIN N. (1997) Foreign direct investment, technological change, and economic growth within Europe. Economic Journal, 107, 1770-1786.

BLOMSTRÖM M., GLOBERMAN S. and KOKKO A. (1999) The determinants of host country spillovers from foreign direct investment: Review and synthesis of the literature, Conference on Inward investment, technological change and growth, NIESR, London, September 1999

BLOMSTRÖM M. and SJOHOLM F. (1999), Technology transfer and spillovers: Does local participation with multinationals matter? European Economic Review 43, 915-923. 
BUFFIE E. (1993), Direct Foreign Investment, Crowding Out, and Underemployment on the Dualistic Economy. Oxford Economic Papers 45, 639-67.

CANTWELL J.A. (1991) The international agglomeration of R\&D, in CASSON M.C. (ed.), Global Research Strategy and International Competitiveness, Basil Blackwell, Oxford.

CATINAT M., CAWLEY R., ILZKOVITZ F., ITALIANER A. and MORS M (1997), Investment Behaviour in Europe: A Comparative Analysis. Recherches Economique de Louvain 54, 277-324.

DE MELLO L.R. (1999) Foreign direct investment-led growth: evidence from time series and panel data. Oxford Economic Papers 51, 133-151.

DRIFFIELD N.L. (1999a), The Indirect Employment Effect of Foreign Direct Investment in the UK. Bulletin of Economic Research 51, 207-221.

DRIFFIELD N.L. (1999b) Regional and industry level spillovers from FDI in the UK. NIESR conference on inward investment, technological change and growth., September 1999.

DRIFFIELD N.L. (2001a) Regional Policy and the impacts of FDI in the UK, in N. Pain (ed.) Inward investment, technological change and growth.

DRIFFIELD N.L. (2001b) The impact on domestic productivity of inward investment in the UK. The Manchester School 69, 103-119.

DRIFFIELD N.L. and MUNDAY M.C. (1998). The Impact of Foreign Direct Investment on UK Manufacturing: Is there a profit squeeze in domestic firms? Applied Economics 30, 705-709.

DRIFFIELD N.L. and MUNDAY M.C. (2000) Industrial performance, agglomeration, and foreign manufacturing investment in the UK. Journal of International Business Studies 31, 21-37. 
DUNNING J.H. (1993) Multinational enterprises and the global economy, London: Addison Wesley.

ELLISON G. and GLAESER E.L. (1999) The geographic concentration of industry: Does natural advantage explain agglomeration? American Economic Review 89, 311-316 GÖRG H. and STROBL E. (1999) Multinational Companies and the Entry of Indigenous Firms: Panel Data Evidence for Ireland. University College Cork Working Paper WP99/8,

GÖRG H. and STROBL E. (2001) Multinational Companies and Productivity Spillovers: A Meta-analysis. Economic Journal 111 F723-739.

HALL B.H. (1992) Investment and Research and Development at the Firm Level: Does the Source of Financing Matter? National Bureau of Economic Research, Working Paper 4096, Cambridge, Massachusetts.

HAMILL J. (1993), Employment Effects of the Changing Strategies of Multinational Enterprises, in BAILEY P., PRISOTTO, A. and RENSHAW G. (ed). Multinationals and Employment, The Global Economy of the 1990s. International Labour Office, Geneva.

HEAD K., RIES J and SWENSON D. (1995). Agglomeration benefits and location choice: Evidence from Japanese manufacturing investments in the United States. Journal of International Economics 38, 223-247.

HEJAZI W. and PAULY P. (2001) Foreign Direct investment and domestic capital formation. Manuscript, University of Toronto.

HIRSCHMAN A. (1958) The Strategy of economic development. Yale University Press, New Haven. 
HOLDEN D.R. and SWALES, J.K. (1995) The additionality, displacemnt and substitution effects of factor subsidies. Scottish Journal of Political Economy 42, 113126.

JONES G. (2002) The development of the Annual Business Inquiry. Available at: http://www.statistics.gov.uk/themes/economy/Articles/General/extracts/downloads/development of ABI Nov 2000.p df

KEANE M.P. and RUNKLE D.E. (1992) On the estimation of panel-data models with serial correlation when instruments are not strictly exogenous. Journal of Business and Economics Statistics 10, 1-9.

KOECHLIN T. (1992), The Responsiveness of Domestic Investment to Foreign Economic Conditions. Journal of Post Keynesian Economics 15, 63-84

MARKUSEN J. and VENABLES A. (1999), Foreign Direct Investment as a Catalyst for Industrial Development. European Economic Review 43, 335-356.

MORRIS J., MUNDAY M. and WILKINSON B. (1993), Working for the Japanese. Athlone, London.

NICKELL S.J. (1979) The investment decisions of firms. Cambridge University Press.

PAUL C.J.M. and SIEGEL D.S. (1999) Scale economies and industry agglomeration externalities: A dynamic cost function approach. American Economic Review 89, 272290

PFANN G.A. (1996) Factor demand models with non-linear short run fluctations. Journal of Economic Dynamics and Control 20, 315-331.

PHELPS N. (1993) Branch plants and the evolving spatial division of labour: A study of material linkage change in the Northern region of England. Regional Studies, 27 87101.

RODRIGUEZ-CLARE A. (1996) Multinationals, linkages and economic development. American Economic Review 86, 852-873.

THOMSEN, T. (2000) Short cuts to dynamic factor demand modelling. Journal of Econometrics 97, 1-23. 
TUROK I. (1993), Inward Investment and Local Linkages: How Deeply Embedded is Silicon Glen? Regional Studies 27, 401-417.

TUROK I. (1996), Linkages in the Scottish Electronics Industry: Further Evidence. Regional Studies 31, 705-711.

WAKELIN K. and GIRMA S. (2000) Are there regional spillovers from FDI in the UK? Paper presented at Globalisation and Labour Markets conference, University of Nottingham, 7th - 8th July 2000.

YOUNG S. HOOD N. and PETERS E. (1994) Multinational enterprises and regional economic development. Regional Studies 28, 657-677. 
Table 1 Results

\begin{tabular}{|c|c|c|c|c|c|c|c|}
\hline \multicolumn{4}{|c|}{ 1984-1992 } & \multicolumn{4}{|c|}{ 1993-1997 } \\
\hline Parameter & Estimate & t-statistic & P-value & Parameter & Estimate & t-statistic & P-value \\
\hline$K_{i r t-1}$ & 0.3687 & $2.12^{* *}$ & {$[.034]$} & $K_{i r t-1}$ & .0944 & $6.73 * *$ & {$[.000]$} \\
\hline$Q_{\text {irt }}$ & 0.1389 & $7.33^{* *}$ & {$[.000]$} & $Q_{i r t}$ & .2041 & $2.75^{* *}$ & [.000] \\
\hline$L s_{i r t}$ & 0.2446 & $3.65^{* *}$ & {$[.000]$} & $L_{i r t}$ & .1509 & $1.93^{*}$ & {$[.006]$} \\
\hline$L u_{i r t}$ & 0.0826 & $4.45^{* *}$ & [.000] & & & & \\
\hline$\Pi_{i r t}$ & 0.0652 & $2.83 * *$ & [.005] & $\Pi_{i r t}$ & .2005 & $2.65^{*}$ & [.100] \\
\hline$K F_{i r t}$ & 0.1625 & $3.24 * *$ & {$[.001]$} & $K F_{\text {irt }}$ & .0311 & $2.00 * *$ & {$[.046]$} \\
\hline Time dummies & & yes & & & & yes & \\
\hline SIC 22 & -0.0277 & $-1.78^{*}$ & [.075] & $\underset{\star}{\text { NACE15(41) }}$ & -0.0226 & $-1.88^{*}$ & [.061] \\
\hline SIC 23 & 0.004 & 0.03 & {$[1.00]$} & NACE16(42) & 0.0291 & 0.6 & {$[.546]$} \\
\hline SIC 24 & -0.0337 & $-1.52^{*}$ & [.129] & NACE17(43) & $\begin{array}{l}-0.0393 \\
\end{array}$ & $-1.44 *$ & [.149] \\
\hline SIC 25 & 0.0473 & $2.07 * *$ & [.039] & NACE18(45) & 0.1207 & $3.02 * *$ & [.003] \\
\hline SIC 26 & 0.0153 & 1.03 & {$[0.31]$} & NACE19(44) & 0.0324 & 1.17 & [.243] \\
\hline SIC 31 & 0.0756 & $5.79 * *$ & {$[.000]$} & NACE20(46) & 0.0655 & $2.30 * *$ & {$[.022]$} \\
\hline SIC 32 & -0.007 & -0.22 & [.826] & NACE21(47) & -0.0437 & $-1.59 *$ & [.112] \\
\hline SIC 33 & -0.007 & $-6.95 * *$ & {$[.000]$} & NACE22(47) & -0.0179 & -0.22 & [.823] \\
\hline SIC 34 & -0.096 & $-4.35^{* *}$ & {$[.000]$} & NACE23(14) & 0.0159 & 0.76 & {$[.448]$} \\
\hline SIC 35 & 0.230 & $15.38 * *$ & {$[.000]$} & NACE24(25) & 0.046 & $1.78^{*}$ & {$[.074]$} \\
\hline SIC 36 & -0.029 & $-5.00 * *$ & {$[.000]$} & NACE25(48) & -0.062 & $-2.42 * *$ & [.016] \\
\hline SIC 37 & -0.022 & $-1.97 * *$ & {$[.048]$} & NACE26(24) & -0.0312 & -1.13 & [.259] \\
\hline SIC 43 & -0.003 & -1.41 & [.159] & NACE27(22) & -0.0213 & -0.81 & [.419] \\
\hline SIC 44 & 0.000 & 0.01 & {$[1.00]$} & NACE28(31) & 0.0309 & 1.28 & {$[.201]$} \\
\hline SIC 45 & 0.052 & $5.45 * *$ & {$[.000]$} & NACE29(32) & -0.2047 & $-3.13^{* *}$ & {$[.002]$} \\
\hline SIC 46 & 0.001 & 0.87 & [.383] & NACE30(33) & -0.0117 & 0.44 & [.658] \\
\hline SIC 47 & -0.068 & $-4.36^{* *}$ & [.000] & NACE31(34) & -0.014 & $6.04 * *$ & {$[.000]$} \\
\hline \multirow[t]{5}{*}{ SIC 48} & -0.001 & -0.24 & [.808] & NACE32(34) & 0.0042 & 0.19 & [.848] \\
\hline & & & & NACE33(35) & 0.0078 & 0.38 & [.698] \\
\hline & & & & NACE34(35) & 0.034 & $4.72 *$ & {$[.000]$} \\
\hline & & & & NACE35(36) & -0.0181 & $2.86 * *$ & [.005] \\
\hline & & & & NACE37(49) & -0.0107 & -0.54 & {$[.584]$} \\
\hline East Anglia & 0.0359 & $4.63 * *$ & {$[.000]$} & East Anglia & 0.0042 & $1.92 *$ & [.056] \\
\hline South West & -0.0574 & $\begin{array}{l}-5.92 * * \\
\end{array}$ & {$[.000]$} & South West & $\begin{array}{l}-0.0078 \\
\end{array}$ & $\begin{array}{ll}-0.38 \\
\end{array}$ & [.698] \\
\hline West Midlands & 0.0231 & $1.46^{*}$ & [.142] & $\begin{array}{l}\text { West } \\
\text { Midlands } \\
\end{array}$ & 0.0340 & $1.72^{*}$ & {$[.085]$} \\
\hline East Midlands & 0.0565 & $3.93^{* *}$ & {$[.000]$} & East Midlands & 0.0181 & $5.66^{* *}$ & {$[.000]$} \\
\hline Yorkshire \& Hum’ & -0.0034 & $-4.38^{* *}$ & {$[.000]$} & $\begin{array}{l}\text { Yorkshire \& } \\
\text { Hum’ }\end{array}$ & -0.0107 & -0.55 & [.584] \\
\hline North West & -0.0035 & $-1.53^{*}$ & [.127] & North West & 0.0159 & 0.75 & [.448] \\
\hline North & -0.0014 & -1.11 & {$[.265]$} & North & 0.0020 & 0.08 & {$[.936]$} \\
\hline Wales & -0.328 & $-4.18^{* *}$ & {$[.000]$} & Wales & -0.350 & $-4.70^{* *}$ & [.000] \\
\hline Scotland & -0.341 & $-5.55 * *$ & {$[.000]$} & Scotland & $\begin{array}{l}-0.0309 \\
\end{array}$ & $-4.81 * *$ & {$[.000]$} \\
\hline Northern Ireland & 0.1592 & $6.14^{* *}$ & {$[.000]$} & $\begin{array}{l}\text { Northern } \\
\text { Ireland }\end{array}$ & 0.2048 & $4.78^{* *}$ & {$[.000]$} \\
\hline
\end{tabular}

${ }^{\star}$ The number in parentheses refers to the SIC(80) code that is closest to the NACE. 


\begin{tabular}{|l|c|c|}
\hline $\mathrm{n}$ & 1320 & 506 \\
\hline Identifying restrictions: Sargan : $\mathrm{p}$-value & {$[0.747]$} & {$[0.513]$} \\
\hline spatial dependence (SARMA $)^{\mathrm{ix}} \sim \chi^{2}(2)$ & $\begin{array}{c}3.716 \\
(\mathrm{p}=0.156)\end{array}$ & \\
\hline Spatial autocorrelation $\sim \chi^{2}(5)^{\mathrm{x}}$ & 7.569 & 5.9812 \\
& {$[0.182]$} & {$[0.308]$} \\
\hline inclusion of inter-regional industry level effects & 1.08 & 1.01 \\
$\chi^{2}(1)$ & $(0.30)$ & $(0.32)$ \\
\hline Serial correlation, LM test, AR(2) ${ }^{\mathrm{xi}} \sim \chi^{2}(1)$ & $2.09 \mathrm{p}$-value $=$ & $1.259[0.261]$ \\
& {$[0.148]$} & \\
\hline inclusion of further lag of FDI variables LR test & $\begin{array}{c}1.61 \mathrm{p} \text {-value } \\
\chi^{2}(1)\end{array}$ & $1.24[0.264]$ \\
\hline
\end{tabular}

Heteroskedastic - consistent standard errors. 


\section{Table 2a}

\section{Non- Assisted Areas}

\begin{tabular}{|c|c|c|c|c|c|c|c|c|}
\hline \multicolumn{5}{|l|}{$1984-1992$} & \multicolumn{4}{|l|}{ 1993-1997 } \\
\hline Parameter & Estimate & \multicolumn{2}{|c|}{ t-statistic } & P-value & Parameter & Estimate & t-statistic & P-value \\
\hline$K_{i r t-1}$ & 0.3687 & \multicolumn{2}{|c|}{$2.12 * *$} & {$[.034]$} & $K_{i r t-1}$ & 0.5112 & $3.62 * *$ & {$[.000]$} \\
\hline$Q_{i r t}$ & 0.1389 & \multicolumn{2}{|c|}{$7.33^{* *}$} & {$[.000]$} & $Q_{i r t}$ & 0.3947 & $5.74 * *$ & {$[.000]$} \\
\hline$L s_{i r t}$ & 0.2446 & \multicolumn{2}{|c|}{$3.65 * *$} & {$[.000]$} & $L_{i r t}$ & 0.7820 & $4.18 * *$ & {$[.000]$} \\
\hline$L u_{i r t}$ & 0.0826 & \multicolumn{2}{|c|}{$4.45^{* *}$} & {$[.000]$} & & & & \\
\hline$\Pi_{i r t}$ & 0.0652 & \multicolumn{2}{|c|}{$2.83 * *$} & {$[.005]$} & $\Pi_{i r t}$ & 0.5638 & $6.64 * *$ & {$[.000]$} \\
\hline$K F_{i r t}$ & 0.1625 & \multicolumn{2}{|c|}{$3.24^{* *}$} & {$[.001]$} & $K F_{\text {irt }}$ & 0.0500 & $2.69 * *$ & {$[.008]$} \\
\hline Time dummies & \multicolumn{4}{|c|}{ yes } & & \multicolumn{3}{|c|}{ yes } \\
\hline Industry dummies & \multicolumn{4}{|c|}{ yes } & & \multicolumn{3}{|c|}{ yes } \\
\hline \multicolumn{2}{|l|}{$\mathrm{n}$} & \multicolumn{3}{|c|}{720} & \multicolumn{4}{|c|}{276} \\
\hline \multicolumn{3}{|c|}{ Identifying restrictions: Sargan : p-value } & \multicolumn{2}{|c|}{$[0.594]$} & \multicolumn{4}{|c|}{$[0.483]$} \\
\hline \multicolumn{3}{|c|}{ spatial dependence (SARMA) $\sim \chi^{2}(2)$} & \multicolumn{2}{|c|}{$3.716 \quad[\mathrm{p}=0.156]$} & \multicolumn{4}{|c|}{$3.558[\mathrm{p}=0.158]$} \\
\hline \multicolumn{3}{|c|}{ Spatial autocorrelation $\sim \chi^{2}(5)$} & \multicolumn{2}{|c|}{$7.569 \quad[0.182]$} & \multicolumn{4}{|c|}{$\sim \chi^{2}(4): 5.972[0.201]$} \\
\hline \multicolumn{3}{|c|}{$\begin{array}{l}\text { inclusion of inter-regional industry } \\
\text { level effects } \chi^{2}(1)\end{array}$} & \multicolumn{2}{|c|}{$\begin{array}{c}1.06 \\
(0.31)\end{array}$} & \multicolumn{4}{|c|}{$\begin{array}{c}0.98 \\
(0.34)\end{array}$} \\
\hline \multicolumn{3}{|c|}{$\begin{array}{l}\text { Serial correlation, LM test, } \mathrm{AR}(2) \sim \\
\chi^{2}(1)\end{array}$} & \multicolumn{2}{|c|}{$2.09 \quad[0.148]$} & \multicolumn{4}{|c|}{$2.47 \quad[0.116]$} \\
\hline \multicolumn{3}{|c|}{$\begin{array}{l}\text { inclusion of further lag of FDI variables } \\
\text { LR test } \chi^{2}(1)\end{array}$} & \multicolumn{2}{|c|}{$1.61[0.204]$} & \multicolumn{4}{|c|}{$1.04[0.307]$} \\
\hline
\end{tabular}

Heteroskedastic - consistent standard errors. 


\section{Table $2 b$}

\section{Assisted Areas}

\begin{tabular}{|c|c|c|c|c|c|c|c|c|}
\hline \multicolumn{5}{|l|}{ 1984-1992 } & \multicolumn{4}{|l|}{$1993-1997$} \\
\hline Parameter & Estimate & \multicolumn{2}{|c|}{ t-statistic } & P-value & Parameter & Estimate & t-statistic & P-value \\
\hline$K_{i r t-1}$ & 0.1660 & \multicolumn{2}{|c|}{$8.43 * *$} & {$[.000]$} & $K_{i r t-1}$ & 0.7640 & $5.19 * *$ & {$[.000]$} \\
\hline$Q_{i r t}$ & 0.5077 & \multicolumn{2}{|c|}{$5.64 * *$} & {$[.000]$} & $Q_{i r t}$ & 0.6527 & $1.53^{*}$ & {$[.126]$} \\
\hline$L s_{i r t}$ & 0.8127 & \multicolumn{2}{|c|}{$2.76^{* *}$} & {$[.006]$} & $L_{i r t}$ & 0.2303 & $4.17 * *$ & {$[.000]$} \\
\hline$L u_{i r t}$ & 0.0247 & \multicolumn{2}{|c|}{$1.68^{*}$} & {$[.093]$} & & & & \\
\hline$\Pi_{i r t}$ & 0.3691 & \multicolumn{2}{|c|}{$3.27 * *$} & {$[.001]$} & $\Pi_{i r t}$ & 0.0991 & 1.03 & {$[.303]$} \\
\hline$K F_{i r t}$ & -0.0332 & \multicolumn{2}{|c|}{$-4.29 * *$} & {$[.000]$} & $K F_{i r t}$ & -0.0104 & $-2.45^{* *}$ & {$[.015]$} \\
\hline Time dummies & \multicolumn{4}{|c|}{ yes } & & \multicolumn{3}{|c|}{ yes } \\
\hline \multicolumn{2}{|l|}{$\mathrm{n}$} & \multicolumn{3}{|c|}{600} & \multicolumn{4}{|c|}{230} \\
\hline \multicolumn{3}{|c|}{ Identifying restrictions: Sargan : p-value } & \multicolumn{2}{|c|}{ [0.733] } & \multicolumn{4}{|c|}{$[0.576]$} \\
\hline \multicolumn{3}{|c|}{ spatial dependence (SARMA) $\sim \chi^{2}(2)$} & \multicolumn{2}{|c|}{$[\mathrm{p}=0.421]$} & \multicolumn{4}{|c|}{$[\mathrm{p}=0.364]$} \\
\hline \multicolumn{3}{|c|}{ Spatial autocorrelation $\sim \chi^{2}(5)$} & \multicolumn{2}{|c|}{$5.694[0.337]$} & \multicolumn{4}{|c|}{$\sim \chi^{2}(4): 4.485[0.344]$} \\
\hline \multicolumn{3}{|c|}{$\begin{array}{l}\text { inclusion of inter-regional industry } \\
\text { level effects } \chi^{2}(1)\end{array}$} & \multicolumn{2}{|c|}{$\begin{array}{c}1.32 \\
(0.25)\end{array}$} & \multicolumn{4}{|c|}{$\begin{array}{c}1.24 \\
(0.27)\end{array}$} \\
\hline \multicolumn{3}{|c|}{$\begin{array}{l}\text { Serial correlation, LM test, } \mathrm{AR}(2) \sim \\
\chi^{2}(1)\end{array}$} & \multicolumn{2}{|c|}{$2.104 \quad[0.148]$} & \multicolumn{4}{|c|}{$1.953 \quad[0.162]$} \\
\hline \multicolumn{3}{|c|}{$\begin{array}{l}\text { inclusion of further lag of FDI variables } \\
\text { LR test } \chi^{2}(1)\end{array}$} & \multicolumn{2}{|c|}{$2.346 \quad[0.125]$} & \multicolumn{4}{|c|}{$1.073[0.300]$} \\
\hline
\end{tabular}

Heteroskedastic - consistent standard errors. 
Figure 1: Share of regional manufacturing employment accounted for by foreign firms.

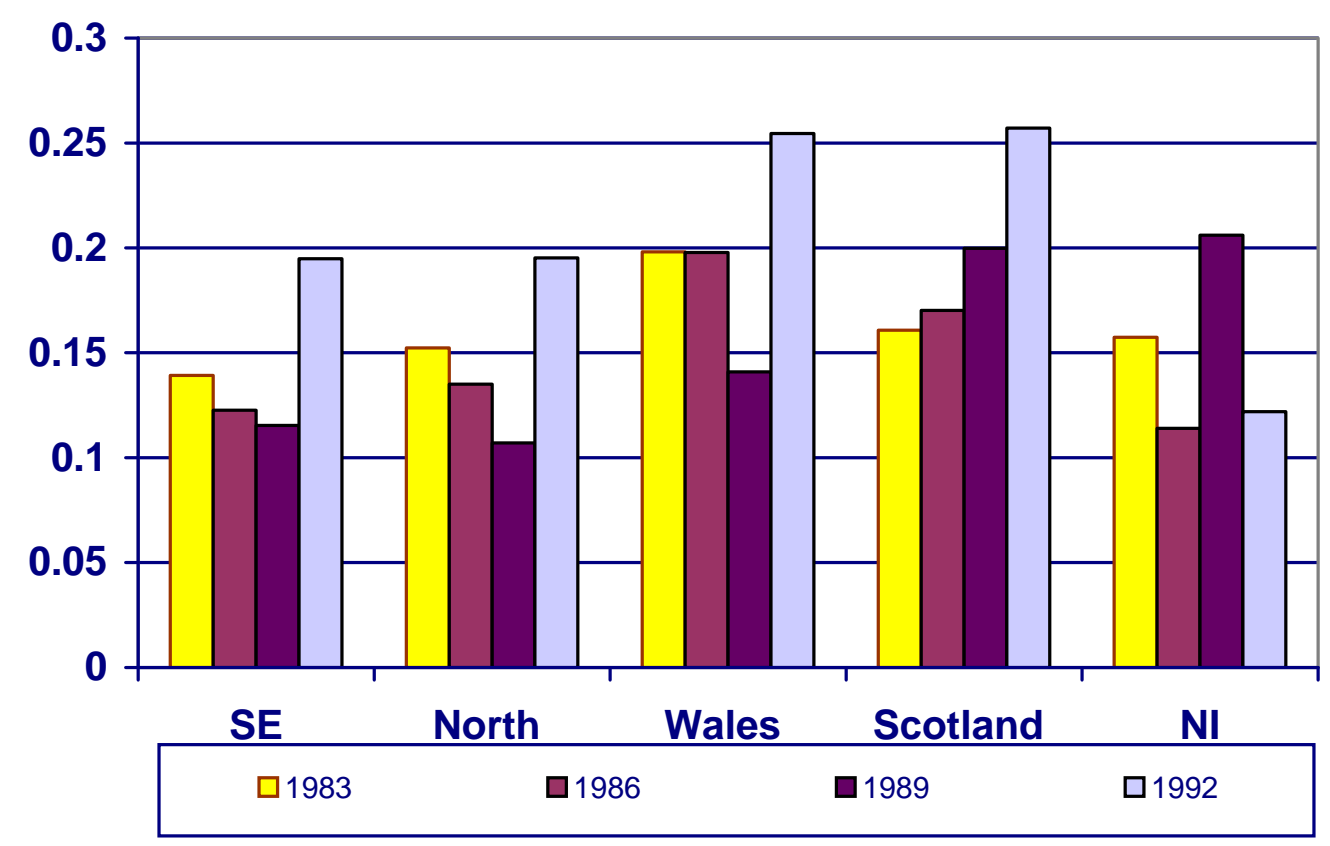

Figure 2: Shares of Foreign employment across industries

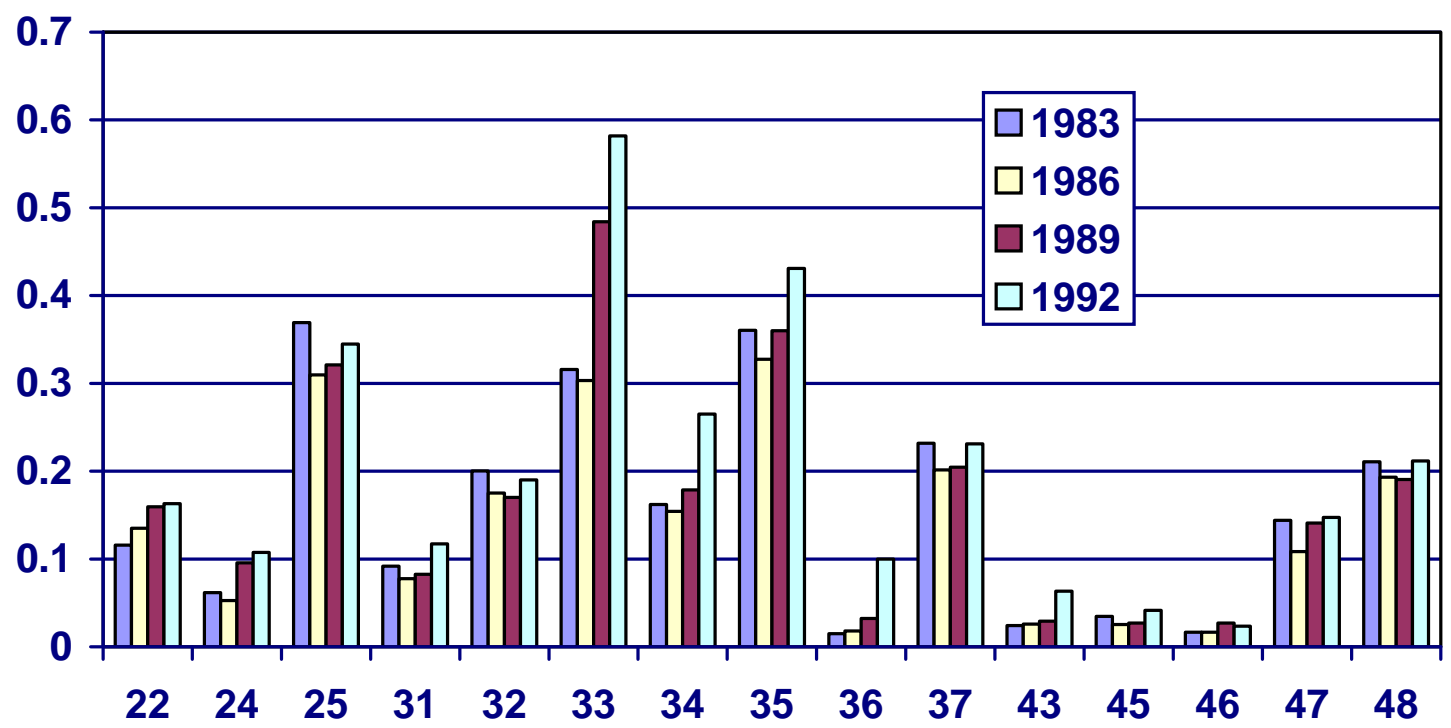


Table 3. Individual Region/ Industry effects of inward FDI

SIC 22 SIC 23 SIC 24 SIC 25 SIC 26 SIC 31 SIC 32 SIC 33 SIC 34 SIC 35 SIC 36 SIC 37 SIC 43 SIC 44 SIC 45 SIC 46 SIC 47 SIC 48

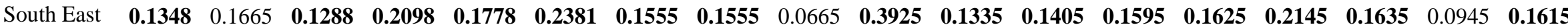

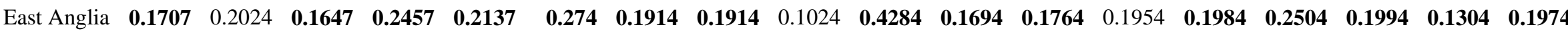

$\begin{array}{llllllllllllllllllll}\text { South West } & 0.0774 & 0.2439 & 0.0714 & \mathbf{0 . 1 5 2 4} & \mathbf{0 . 1 2 0 4} & \mathbf{0 . 1 8 0 7} & 0.0981 & 0.0981 & 0.0091 & \mathbf{0 . 3 3 5 1} & 0.0761 & 0.0831 & 0.1021 & \mathbf{0 . 1 0 5 1} & \mathbf{0 . 1 5 7 1} & \mathbf{0 . 1 0 6 1} & 0.0371 & \mathbf{0 . 1 0 4 1}\end{array}$

$\begin{array}{llllllllllllllllllllll}\text { West } & 0.1579 & 0.3244 & 0.1519 & 0.2329 & 0.2009 & 0.2612 & 0.1786 & 0.1786 & 0.0896 & 0.4156 & 0.1566 & 0.1636 & 0.1826 & 0.1856 & 0.2376 & 0.1866 & 0.1176 & 0.1846\end{array}$

Midlands

East

Midlands

Yorkshire

Humbersid

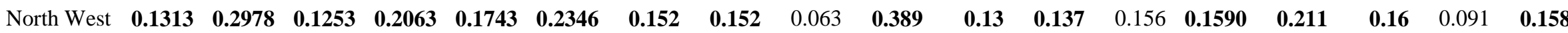
$\begin{array}{lllllllllllllllllllllll}\text { North } & & 0.1334 & 0.2999 & \mathbf{0 . 1 2 7 4} & \mathbf{0 . 2 0 8 4} & \mathbf{0 . 1 7 6 4} & \mathbf{0 . 2 3 6 7} & \mathbf{0 . 1 5 4 1} & \mathbf{0 . 1 5 4 1} & 0.0651 & \mathbf{0 . 3 9 1 1} & \mathbf{0 . 1 3 2 1} & \mathbf{0 . 1 3 9 1} & 0.1581 & \mathbf{0 . 1 6 1 1} & \mathbf{0 . 2 1 3 1} & \mathbf{0 . 1 6 2 1} & 0.0931 & \mathbf{0 . 1 6 0 1}\end{array}$

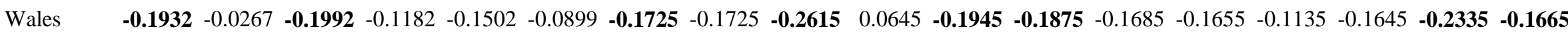

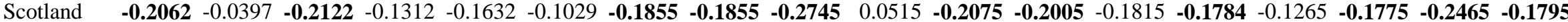

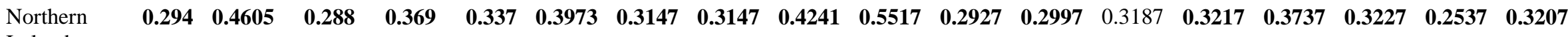

Ireland

Bold denotes overall coefficient different from zero (including the default coefficient) z-stat. 1\% confidence interval. 


\footnotetext{
${ }^{\mathrm{i}}$ Formerly the Northern Development Company

${ }^{\text {ii }}$ For empirical treatments of this type of model, see Barrell and Pain (1996) or Bajo-Rubio and SosvillaRivero (1994) for example.

${ }^{\text {iii }}$ It is possible to augment this model with various inter-regional, or inter-industry effects, in addition to the standard tests for spatial dependence or spatial autocorrelation. Such effects however are found to be insignificant in this model, and the test statistic for the inter-regional industry level effect is reported in the diagnostics in the results tables.

${ }^{\text {iv }}$ North of England, West Midlands, Wales, Scotland, Northern Ireland.

${ }^{v}$ The definitions of both the industries, and the regions can be found in any Census of Production Publication, ONS.

${ }^{\mathrm{vi}}$ We are grateful to an anonymous referee of this journal for pointing out this distinction.

${ }^{\text {vii }}$ For example, the elasticity of domestic investment with respect to FDI, for industry $i$, region $r$ can be given as $\beta_{5}+\mu_{\mathrm{i}}+\phi_{\mathrm{r}}$

viii Capital costs are calculated by estimating the capital stock as the sum of all investments for the previous 10 years, multiplied by $4 \%$, as the average ROCE for the period. This is calculated from a sample of over 1000 firms from the FAME data base for the relevant industries over the period.

${ }^{\text {ix }}$ This is based on the test statistic presented by Anselin and Florax (1995)

${ }^{\mathrm{x}}$ This is based on the test statistic presented by Anselin and Kelejian (1997)

${ }^{x i}$ This LM test is outlined on Baltagi (1995) pp. 93
} 